tion. Biochim Biophys Acta 278:89-100

14. Blauer $\mathrm{G}$, Wagniere $\mathrm{G} 1975$ Conformation of bilirubin and biliverdin in their complexes with albumin. J Am Chem Soc 97:1949-1954

15. Ennever JF, Sobel M, McDonagh AF, Speck WT 1984 Phototherapy for neonatal jaundice: in vitro comparison of light sources. Pediatr Res 18:667670

16. Costarino AT, Ennever JF, Baumgart S, Speck WT, Paul M, Polin RA 1985 Bilirubin photoisomerization in premature neonates under low- and highdose phototherapy. Pediatrics 75:519-522

17. Lamola AA, Flores J, Doleiden FH 1982 Quantum yield and equilibrium position of the configurational photoisomerization of bilirubin bound to human serum albumin. Photochem Photobiol 35:649-654

18. Deleted in proof.

19. Andrew G, Chan G, Schiff D 1976 Lipid metabolism in the neonate I. The effects of Intralipid infusion on plasma triglyceride and free fatty acid concentrations in the neonate. J Pediatr 88:273-278

20. Thiessen H, Jacobsen J, Brodersen R 1972 Displacement of albumin-bound bilirubin by fatty acids. Acta Paediatr Scand 61:285-288

21. Andrew G, Chan G, Schiff D 1976 Lipid metabolism in the neonate II. The effect of Intralipid on bilirubin binding in vitro and in vivo. J Pediatr 88:279_ 284

22. Odell GB, Cukier JO, Ostrea EM, Maglalang AC, Poland RL 1977 The influence of fatty acids on the binding of bilirubin to albumin. $J$ Lab Clin Med 89:295-307

23. Spear ML, Stahl GE, Paul MH, Engler JM, Pereira GR, Polin RA 1985 The effect of 15-hour fat infusions of varying dosage on bilirubin binding to albumin. JPEN 9:144-147

24. Brodersen R 1982 Physical chemistry of bilirubin: Binding to macromolecules and membranes. In: Heirwegh KPM, Brown SB (eds) Bilirubin, Vol 1. CRC Press, Boca Raton, FL, pp 75-123

\title{
Announcement
}

\section{Symposium on Developmental Gastroenterology}

The Ohio State University and the Children's Hospital Research Foundation, Columbus, OH will hold the First Wexner Symposium at the Hyatt Regency Hotel from September 13 through September 15, 1987. The symposium has been approved for 10 hours of CME credit.

Invited faculty: Vay Liang W. Go, M.D.; Michael D. Gershon, M.D.; Alan Lucas, M.B., B. Chir, M.R.C.P.; William Balisteri, M.D.; Susan J. Henning, Ph.D.; Otakar Koldovsky, M.D., Ph.D.; Zane Cohen, M.D., F.R.C.S.(C), F.A.C.S.; W. Allan Walker, M.D.

Major topics: bacterial colonization of the gut; gut hormone responses; action of pancreatic polypeptide; signaling and neural messages in the gut; endogenous intestinal hormones; hormones in milk; glucose polymer assimilation; newborn colonic function; intestinal vascular regulation; immune function in the gut; and immunology of intestinal transplantation.

For further information contact: Howard R. Sloan, M.D., Ph.D., Children's Hospital, 205 Ross Hall, 700 Children's Drive, Columbus, $\mathrm{OH} 43205$ or call 614-461-2212. 